\title{
Sichong formula inhibits the proliferation and migration of human gastric cancer cells
}

This article was published in the following Dove Press journal:

OncoTargets and Therapy

\author{
Meng Wang' \\ Zhaochun Tian ${ }^{2}$ \\ Yong Zhu' \\ Jian Ding' \\ Chen $\mathrm{Li}^{1}$ \\ Yongkun Zhou' \\ Yunjie Zhang'
}

'Department of General Surgery, Affiliated Hospital of Shandong University of Traditional Chinese Medicine, Jinan 2500 I4, People's Republic of China;

${ }^{2}$ Chinese Medicine Ophthalmology, Shandong Provincial Qianfoshan Hospital, Jinan 2500I4, People's Republic of China

Correspondence: Yongkun Zhou; Yunjie Zhang

Department of General Surgery, Affiliated Hospital of Shandong University of Traditional Chinese Medicine, No. 16369. Jingshi Road, Jinan City, Shandong Province 2500 I4, People's Republic of China

Tel +86 I37 93I8 8090; +86 I3964063375

Email zhouyongkun03107@126.com;

zhangyunjielI30@163.com
Purpose: Traditional Chinese medicine (TCM) has gained increasing attention for the treatment of multiple chronic diseases, such as cancer. Here we aim to identify the antitumor activity of Sichong formula, a novel TCM, in human gastric cancer cells and investigate the underlying mechanisms.

Methods: The AGS and MKN45 gastric cancer cells were treated with Sichong formula at different concentrations. The proliferation rates were tested by CCK- 8 and colony formation assays. Cell migration and invasion were tested by scratch and transwell assays. Gelatin zymography was used to detect the matrix metalloproteinase 9 (MMP9) activity in cell suspendents. Cell apoptosis was analyzed by Annexin V/PI staining and flow cytometry. The expression of interest proteins was tested by Western blot.

Results: Cell proliferation analysis indicated that Sichong formula inhibited cell viability of AGS and MKN45 cells in a dose- and time-dependent manner. The IC50 values were 240 $\mu \mathrm{g} / \mathrm{mL}$ and $200 \mu \mathrm{g} / \mathrm{mL}$ for AGS and MKN45 cells, respectively. Furthermore, we found that Sichong formula could inhibit the invasion and migration of gastric cancer cells, which might be mediated by the downregulation of MMP9 activity. Flow cytometry results indicated that Sichong formula induced apoptosis in gastric cancer cells through upregulation of $\mathrm{Bax} / \mathrm{Bc1} 2$ ratio and activation of caspase cascade. The results from Western blot indicated that Sichong formula resulted in cell autophagy and inactivation of AKT signaling pathway.

Conclusion: Our data suggest that Sichong formula inhibits the proliferation and migration and induces apoptosis in human gastric cancer cells. The inhibitory effect of Sichong formula was, at least partly, mediated by cell autophagy and AKT pathway.

Keywords: apoptosis, invasion, migration, MMP9

\section{Introduction}

Gastric cancer, the fourth most common cancer worldwide, has remained a major lifethreatening disease for a long time. ${ }^{1}$ In addition, gastric cancer is the second leading cause of cancer deaths in the world, subsequent only to lung cancer, resulting in 650,000 deaths each year. ${ }^{2,3}$ Due to scarce early clinical manifestations and high tendency to metastasize, patients with gastric cancer are frequently diagnosed in advanced stages. Despite significant advances in surgical treatment, chemotherapy, and radiation therapy for cancer, the 5-year survival rate of gastric cancer remains poor, at approximately $20-30 \%{ }^{4}$ Therefore, it is urgently needed to explore new antitumor drugs with good efficacy and low toxicity for patients with gastric cancer.

Traditional Chinese medicine (TCM) has been applied in China for thousands of years and is currently receiving great attention due to its multitarget and overall regulation in the treatment of tumors. Clinically, TCM is frequently used as adjuvant therapy 
during recovery of cancer patients and postsurgical radiotherapy and chemotherapy. ${ }^{5-7}$ According to in vitro and in vivo studies, TCM might be beneficial for gastric cancer patients by inhibiting the invasion of cancer cells, inducing apoptosis, suppressing prostate cancer dependent angiogenesis, and downregulating human androgen receptors. ${ }^{8,9}$ Sichong formula is composed of Earthworm (Dilong), Scolopendra (Wugong), Scorpion (Quanxie), and Eupolyphaga (Tubie). Sichong formula is a TCM compound from clinical experience, mainly used for the treatment of peripheral vascular diseases such as varicose vein of lower limbs, and it has been proved to induce apoptosis in hepatocellular carcinoma cells. However, as far as we know, there are no studies investigating the effects of Sichong formula on cellular behaviors of gastric cancer cells and the underlying mechanisms.

In this study, we explored the antitumor properties of Sichong formula in AGS and MKN-45 gastric cancer cells. It was demonstrated that Sichong formula could inhibit the proliferation and induce apoptosis in AGS and MKN-45 cells. Moreover, Sichong formula restrained the metastatic capability of AGS and MKN45 cells. Mechanistically, we found that Sichong formula downregulated AKT pathway and induced cell autophagy through regulating protein expression.

\section{Materials and methods}

\section{Cell culture}

Human gastric cancer cell lines (AGS and MKN45) and normal gastric mucosal epithelial cell line (GES-1) were purchased from American Type Culture Collection (Manassas, VA, USA). Both cell lines were cultured in Roswell Park Memorial Institute (RPMI)-1640 medium supplemented with 10\% FBS (Thermo Fisher Scientific, Waltham, MA, USA) at $37^{\circ} \mathrm{C}$ in a humidified atmosphere containing $5 \% \mathrm{CO}_{2}$.

\section{Dose-dependent assay}

The Sichong tablets were ground into fine powder, dissolved in water, and then filtered by a $0.22 \mu \mathrm{m}$ filter. When cell confluence reached $90 \%$, AGS and MKN45 cells were trypsinized and prepared as a cell suspension. Then, the cells were seeded into a 96-well plate at 3000 cells per well and cultured 12 hrs for attachment. Subsequently, a medium containing a gradient of Sichong formula was added to each well at a final concentration of $(0 \mu \mathrm{g} / \mathrm{mL}, 5$ $\mu \mathrm{g} / \mathrm{ml}, 10 \mu \mathrm{g} / \mathrm{mL}, 20 \mu \mathrm{g} / \mathrm{mL}, 40 \mu \mathrm{g} / \mathrm{mL}, 80 \mu \mathrm{g} / \mathrm{mL}, 120$ $\mu \mathrm{g} / \mathrm{mL}, 160 \mu \mathrm{g} / \mathrm{mL}, 200 \mu \mathrm{g} / \mathrm{mL}, 300 \mu \mathrm{g} / \mathrm{mL}, 400 \mu \mathrm{g} / \mathrm{mL}$, and $500 \mu \mathrm{g} / \mathrm{mL}$ ). After $48 \mathrm{hrs}, 10 \mu \mathrm{L}$ of CCK 8 reagent was added to each well, and the mixture was incubated for 1.5 hrs in a $37^{\circ} \mathrm{C}$ incubator. The OD values at $450 \mathrm{~nm}$ were detected using a microplate reader (Multiskan Ex, Thermo Scientific, Waltham, MA, USA), and a dose-dependent curve was plotted to calculate IC50 values.

\section{Proliferation assays CCK8 assay}

Human gastric cancer cells were planted into a 96-well plate at a density of 3000 per well. After treatment with 80 $\mu \mathrm{g} / \mathrm{mL}$ of Sichong formula, cells in each well were added with $10 \mu \mathrm{L}$ CCK 8 solution at regular time points ( $0 \mathrm{hrs}, 24$ hrs, $48 \mathrm{hrs}$, and $72 \mathrm{hrs}$ ) and incubated for $2 \mathrm{hrs}$. Cell viability was determined by detecting the OD values at $450 \mathrm{~nm}$.

\section{Colony formation assay}

Human gastric cancer cells were treated with $80 \mu \mathrm{g} / \mathrm{mL}$ of Sichong formula for $48 \mathrm{hrs}$. Then, cells were collected and seeded in a $6-\mathrm{cm}$ dish at a total number of 500. After being normally cultured for 14 days, the cells were fixed with methanol, stained with $0.1 \%$ crystal violet for $20 \mathrm{mins}$, and washed twice with PBS. Then, gastric cancer cells were visualized with a camera, and the number of formed colonies was counted.

\section{Transwell invasion and migration assays}

AGS or MKN45 cells pretreated with Sichong formula (80 $\mu \mathrm{g} / \mathrm{mL}$ ) were distributed in RPMI-1640 medium and added at $2 \times 10^{4}$ cells into a transwell insertion (with $8 \mathrm{~mm}$ pore size; Corning, New York, NY, USA). The transwell membrane was precoated with Matrigel (BD Biosciences, Bedford, MA, USA). The bottom chambers were supplemented with $500 \mu \mathrm{L}$ of RPMI-1640 medium containing $5 \%$ FBS was included as an inducer. Furthermore, cells were cultured for $48 \mathrm{hrs}$. After that, the noninvaded cells were removed by using a cotton swab, and the invaded cells on the bottom of the transwell membrane were fixed by methanol and stained with $0.1 \%$ crystal violet. The visualization of invaded cells was performed using a light microscopy (Nikon, Tokyo, Japan). The protocol for migration assays was similar to the invasion tests, excluding the inserts that were not enclosed with precoating of Matrigel.

\section{Scratch assay}

The gastric cancer cells were seeded into a 24-well plate. Cells were continuously cultured to $100 \%$ confluency to 
form a monolayer. A single-line wound was formed by scratching the cell monolayer with a $100 \mu \mathrm{L}$ pipet tip. Cell monolayer was washed with PBS to remove debris. Sichong formula $(80 \mu \mathrm{g} / \mathrm{mL}$ ) in RPMI-1640 medium (no containing FBS) was used to incubate cells. After being cultured in a $37^{\circ} \mathrm{C}$ incubator for another $24 \mathrm{hrs}$, the wound was imaged under a light microscope (Nikon). Wound area was quantified by using an ImageJ software.

\section{Gelatin zymography}

AGS and MKN45 cells were treated with $80 \mu \mathrm{g} / \mathrm{mL}$ Sichong formula for $48 \mathrm{hrs}$, and thereafter, the supernatants were harvested. The proteolytic activity of matrix metalloproteinase 9 (MMP9) was evaluated by using gelatin zymography. The gel of $10 \%$ SDS-PAGE containing $0.5 \mathrm{mg} / \mathrm{mL}$ gelatin was prepared. The proteins were added into each lane at a total protein content of $3 \mu \mathrm{g}$ and then separated by SDSPAGE electrophoresis. Gels were incubated twice in an eluent $\left(2.5 \%\right.$ Triton $\mathrm{X}-100,50 \mathrm{mM}$ Tris- $\mathrm{HCl}, 5 \mathrm{mmol} / \mathrm{L} \mathrm{CaCl}_{2}$, $\mathrm{pH}$ 7.6) for 40 mins. Then, gels were washed twice with a rinse solution ( $50 \mathrm{mM}$ Tris- $\mathrm{HCl}, 5 \mathrm{mmol} / \mathrm{L} \mathrm{CaCl}_{2}, \mathrm{pH} 7.6$ ) for $20 \mathrm{mins}$, and placed in the incubation solution $(50 \mathrm{mM}$ Tris- $\mathrm{HCl}, 5 \mathrm{mmol} / \mathrm{L} \mathrm{CaCl} 2,0.02 \%$ Brij-35, $\mathrm{pH}$ 7.6) for 42 hrs at $37^{\circ} \mathrm{C}$. After incubation, gels were stained with $0.25 \%$ Coomassie brilliant blue and destained in $7.5 \%$ acetic acid with 20\% methanol. MMP9 activity was represented by a white band on the blue gel.

\section{Flow cytometry for apoptosis analysis}

After treating with Sichong formula $(80 \mu \mathrm{g} / \mathrm{mL})$ for $48 \mathrm{hrs}$, the cells were harvested and centrifuged for 3 mins at 1000 g. Then, the cells were washed in cold PBS and stained at room temperature for 15 mins with Annexin V and propidium iodide (Life Technologies, Franklin Lakes, NJ, USA) in the dark. Cell apoptosis was analyzed using a flow cytometer (BD Biosciences, San Jose, CA, USA) and Flowjo software (Tree Star Corp, Ashland, OR, USA).

\section{Western blot}

After treated with $80 \mu \mathrm{g} / \mathrm{mL}$ Sichong formula for $48 \mathrm{hrs}$, gastric cancer cells were lysed by aradio-immunoprecipitation assay Lysis Buffer (CWBIO, Beijing, China) added with $1 \%$ protease inhibitor. A BCA method (Beyotime, Beijing, China) was used for the quantification of protein concentration. $20 \mu \mathrm{g}$ of total proteins was taken out and subjected to $10 \%$ SDS-PAGE electrophoresis. The protein bands were then electroblotted onto apolyvinylidene difluoride membrane (Millipore, Bedford, MA, USA). After blocking in
TBST buffer (TBS buffer with $0.1 \%$ Tween-20) containing $5 \%$ BSA for $1 \mathrm{hr}$ at room temperature, protein bands were successively incubated with primary antibodies at $4^{\circ} \mathrm{C}$ overnight and secondary antibodies for $1 \mathrm{hr}$ at room temperature. Then, protein bands were washed by TBST buffer for three times every 5 mins and visualized using Immobilon western (Millipore Co.). The primary antibodies against $\mathrm{Bcl} 2$, Bax, C-Caspase 3, $\alpha$-tubulin, LC-3, Beclin1, P62, AKT, p-AKT, and Cyclin D1 were purchased from Cell Signaling Technology (Beverly, MA, USA). All secondary antibodies were purchased from Invitrogen (Carlsbad, CA, USA).

\section{Statistical analysis}

All data analysis was performed using GraphPad Prism 7 (GraphPad Software, San Diego, CA, USA). The results were expressed as means $\pm \mathrm{SD}$ of three independent experiments. Differences between two independent groups were evaluated with Student's $t$-test. Statistical significance was established at a value of $P<0.05$.

\section{Results}

\section{Inhibition of Sichong formula on the proliferation of gastric cancer cells}

Human gastric cancer cell lines, AGS and MKN45, were treated with Sichong formula at a concentration gradient $(0$ $\mu \mathrm{g} / \mathrm{mL}, 5 \mu \mathrm{g} / \mathrm{mL}, 10 \mu \mathrm{g} / \mathrm{mL}, 20 \mu \mathrm{g} / \mathrm{mL}, 40 \mu \mathrm{g} / \mathrm{mL}, 80 \mu \mathrm{g} / \mathrm{mL}$, $120 \mu \mathrm{g} / \mathrm{mL}, 160 \mu \mathrm{g} / \mathrm{mL}, 200 \mu \mathrm{g} / \mathrm{mL}, 300 \mu \mathrm{g} / \mathrm{mL}, 400 \mu \mathrm{g} / \mathrm{mL}$, and $500 \mu \mathrm{g} / \mathrm{mL}$ ). After $48 \mathrm{hrs}$, the inhibitory effect of Sichong formula on gastric cancer cells was detected by CCK-8 assay. The results indicated that Sichong formula inhibited the proliferation of AGS and MKN45 cells in a concentration-dependent manner (Figure 1A and B). The significant cytotoxic effect of Sichong formula was starting at a concentration of $40 \mu \mathrm{g} / \mathrm{mL}$ for both gastric cancer cell lines $(P<0.05)$. The calculated IC50 values were $240 \mu \mathrm{g} / \mathrm{mL}$ and $200 \mu \mathrm{g} / \mathrm{mL}$ for AGS and MKN45 cells, respectively. 80 $\mu \mathrm{g} / \mathrm{mL}$ was then selected for the subsequent experiments. To test the relationship between drug toxicity and incubation time, AGS and MKN45 cells were treated with $80 \mu \mathrm{g} / \mathrm{mL}$ of Sichong formula and subjected to a CCK-8 detection at 0 hrs, $24 \mathrm{hrs}, 48 \mathrm{hrs}$, and $72 \mathrm{hrs}$. The results also suggested that the cell viability of AGS and MKN45 cells was inhibited by Sichong formula in a time-dependent manner (Figure $1 \mathrm{C}$ and D). After $72 \mathrm{hrs}$ of incubation, cell viability was, respectively, decreased to 50.0\% and 59.5\% in AGS and MKN45 cells. Moreover, colongenic ability of gastric cancer cells was also detected. It was suggested that the number of formed 
A

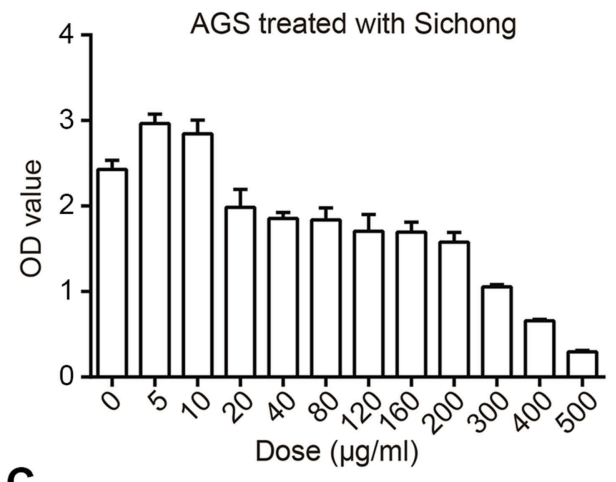

C

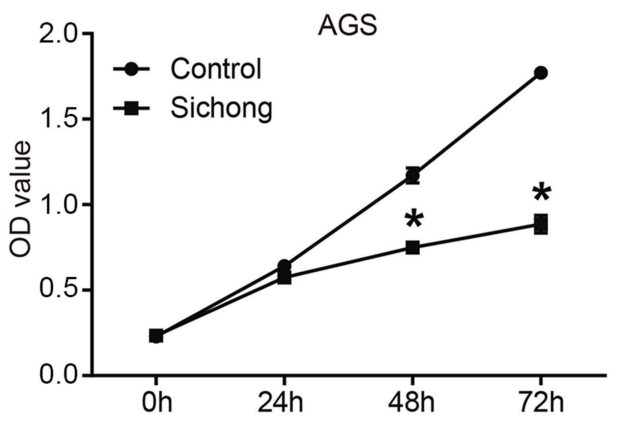

$\mathbf{E}$

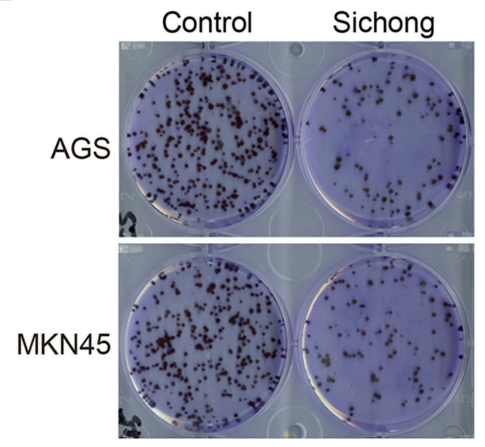

B
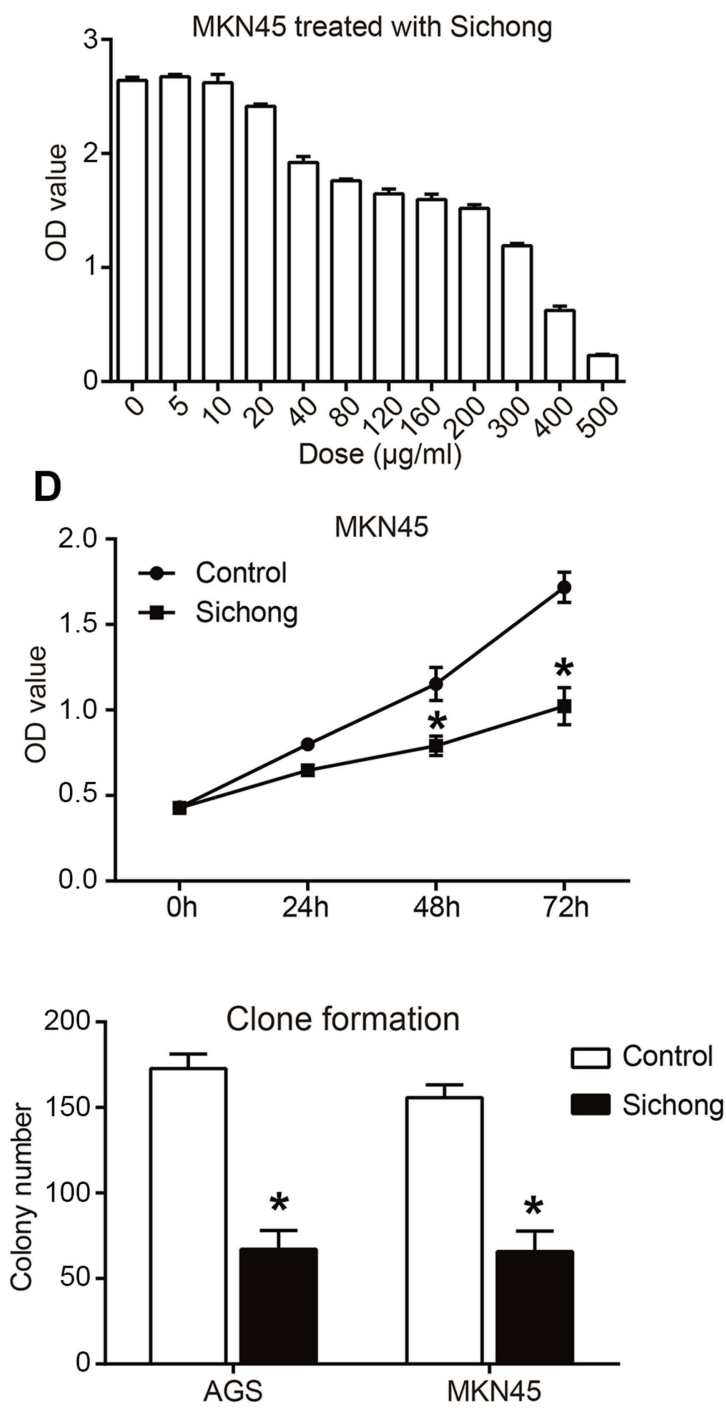

Figure I Sichong formula inhibited gastric cancer cell proliferation in a dose- and time-dependent manner. A concentration gradient of Sichong formula $(0 \mu \mathrm{g} / \mathrm{mL}, 5 \mu \mathrm{g} / \mathrm{mL}$, $10 \mu \mathrm{g} / \mathrm{mL}, 20 \mu \mathrm{g} / \mathrm{mL}, 40 \mu \mathrm{g} / \mathrm{mL}, 80 \mu \mathrm{g} / \mathrm{mL}, 120 \mu \mathrm{g} / \mathrm{mL}, 160 \mu \mathrm{g} / \mathrm{mL}, 200 \mu \mathrm{g} / \mathrm{mL}, 300 \mu \mathrm{g} / \mathrm{mL}, 400 \mu \mathrm{g} / \mathrm{mL}$, and $500 \mu \mathrm{g} / \mathrm{mL})$ was used to incubate with (A) AGS and (B) MKN45 gastric cancer cells for 48 hrs. Cell viability was detected by a CCK-8 assay. The calculated IC50 values were $240 \mu \mathrm{g} / \mathrm{mL}$ and $200 \mu \mathrm{g} / \mathrm{mL}$ for AGS and MKN45 cells, respectively. (C) AGS and (D) MKN45 cells were treated with $80 \mu \mathrm{g} / \mathrm{mL}$ and cell viability was detected at $0 \mathrm{hr}, 24 \mathrm{hrs}, 48 \mathrm{hrs}$, and $72 \mathrm{hrs}$. (E) Clone formation ability of AGS and MKN45 cells treated with Sichong formula $(80 \mu \mathrm{g} / \mathrm{mL})$ was tested. All experiments were performed at 3 times. $* P<0.05$.

colonies significantly reduced in AGS and MKN45 cells treated with Sichong formula (Figure 1E, $P<0.05$ ).

Taken together, these data suggested that Sichong formula inhibited the proliferation ability of human gastric cancer cells in a dose- and time-dependent manner.

\section{Influence of Sichong formula on the invasion and migration of gastric cancer cells}

To investigate whether Sichong formula might influence gastric cancer migration, we detected cell invasion and migration in AGS and MKN45 cells. Transwell assay results indicated the number of invaded cells in Sichong formula-treated group was significantly less than the control group (Figure 2, $P<0.05$ ). Migration cell number was also significantly decreased in Sichong treatment group (Figure 2, $P<0.05$ ). Moreover, cell migration ability of gastric cancer cells was also detected using a scratch assay. It was suggested that the migration of AGS and MKN45 cells across the wound edges was remarkably slower than that of the control group (Figure 3A and B). Gelatin zymography indicated that Sichong formula significantly inhibited the activation of MMP9 (Figure 3C). 
A

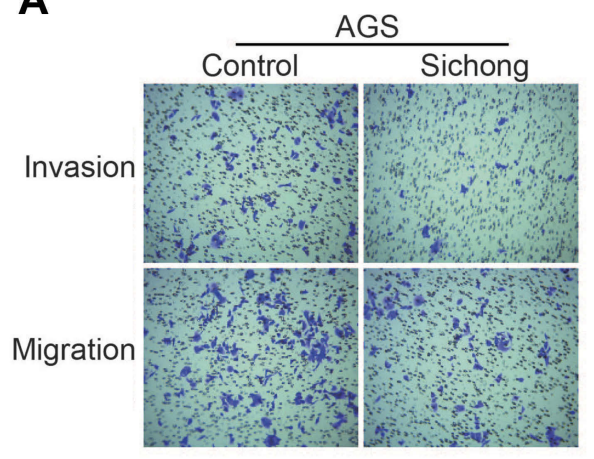

B

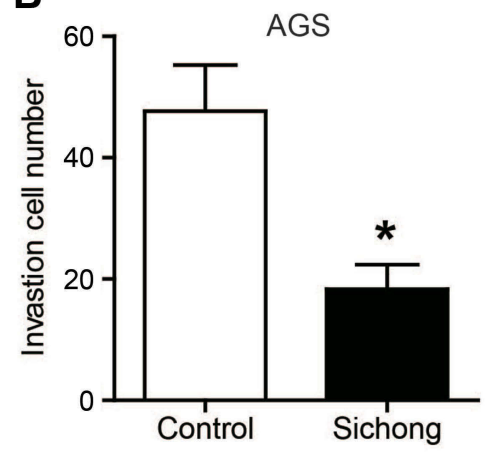

C

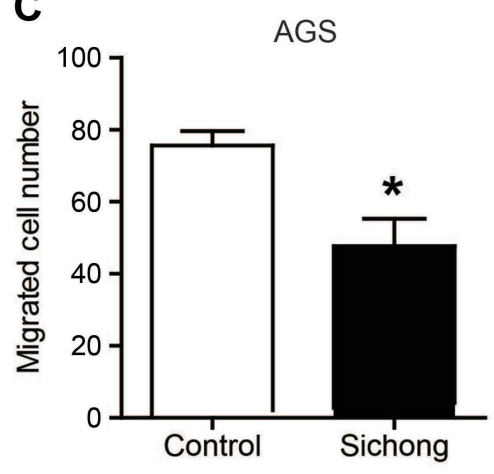

E

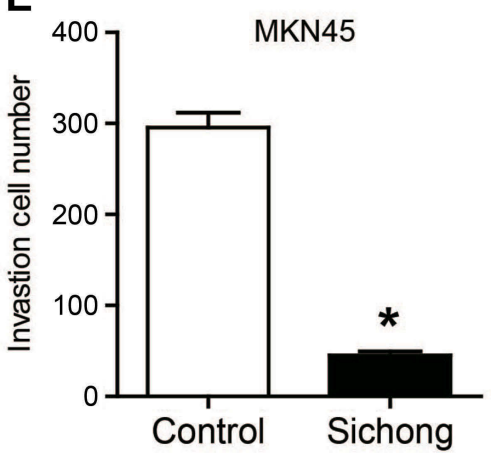

D
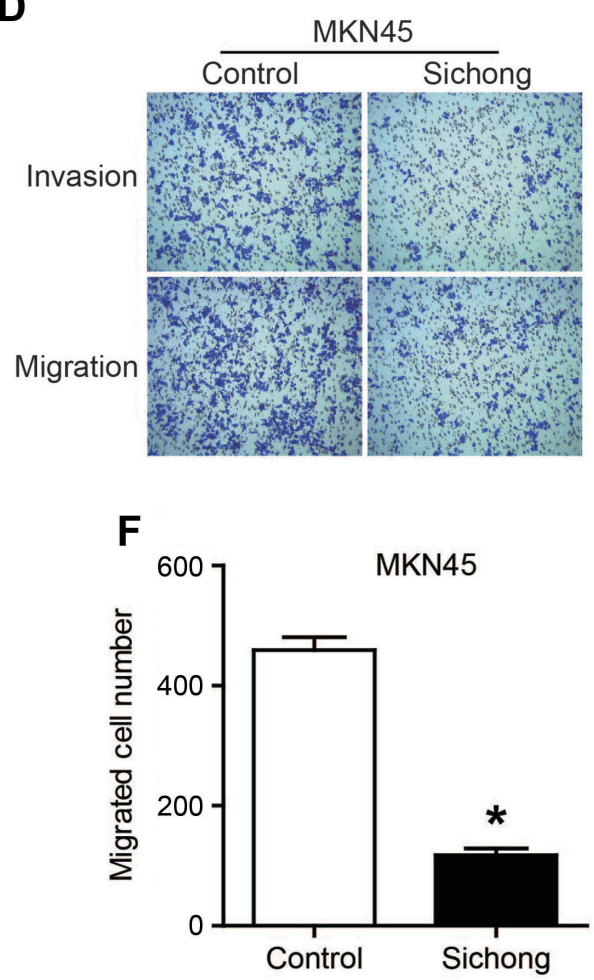

Figure 2 Sichong formula treatment inhibited the invasion and migration abilities of gastric cancer cells in transwell assays. (A) and (D) Theinvasion and migration abilities of human AGS and MKN45 cells were detected by transwell assays, and cells were imaged under a light microscope. (B, C) and (E, F) The statistical results of invaded or migrated cells. The treatment regimen of Sichong formula was $80 \mu \mathrm{g} / \mathrm{mL}$ for $48 \mathrm{hrs}$. All experiments were performed at 3 times. $* P<0.05$.

Taken together, Sichong formula suppressed the invasion migration abilities of gastric cancer cells, which might be due to decreased MMP9 activity.

\section{Induction of apoptosis by Sichong formula in gastric cancer cells}

In order to investigate whether cell apoptosis contributed to the inhibitory effects of Sichong formula on gastric cancer cells, an Annexin V/PI assay was performed. Early apoptotic cells were distributed in the lower-right quadrant $\left(\right.$ Annexin $\left.\mathrm{V}^{+} / \mathrm{PI}^{-}\right)$and late apoptotic cells were in the upper-right quadrant (Annexin $\left.\mathrm{V}^{+} / \mathrm{PI}^{+}\right)$. As shown in Figure $4 \mathrm{~A}$ and $\mathrm{B}$, total apoptosis percentage was increased from $(4.03 \pm 0.23) \%$ in the control group to $(23.44 \pm 1.2) \%$ in Sichong formula-treatment group in AGS cells and $(4.63 \pm 0.31) \%$ to $(24.76 \pm 2.1) \%$ in MKN45 (both $P<0.05$ ). Next, we investigated whether mitochondrial apoptosis pathway was influenced by Sichong formula.

As shown in Figure 4C, Sichong formula treatment led to a significant downregulation of $\mathrm{Bcl} 2$ and upregulation of $\mathrm{Bax}$, thus elevating $\mathrm{Bax} / \mathrm{Bcl} 2$ ratio. The cleaved Caspase 3, an apoptotic executor, was also upregulated by Sichong formula (Figure 4C). In addition, Sichong formula treatment also increased the total apoptosis percentage of normal gastric mucosal epithelial cell line GES-1 (Figure 4D) $(4.613 \pm 0.27 \%$ 
A

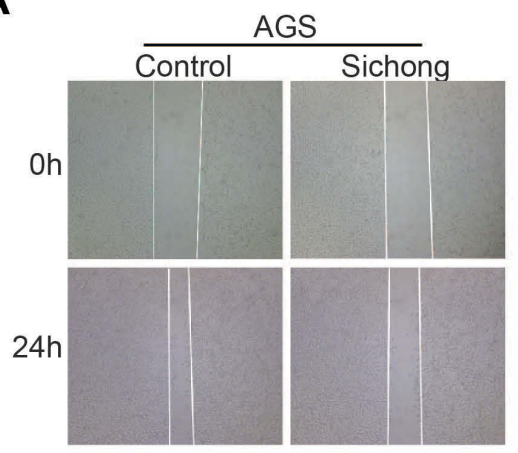

B

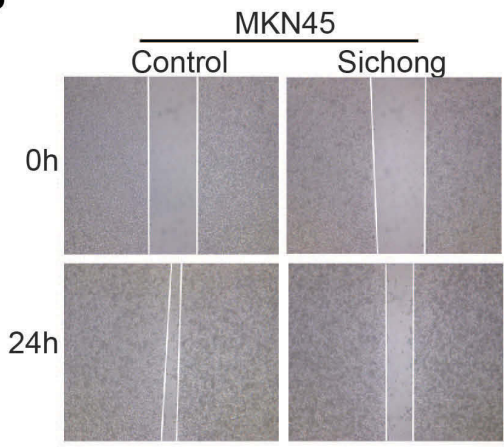

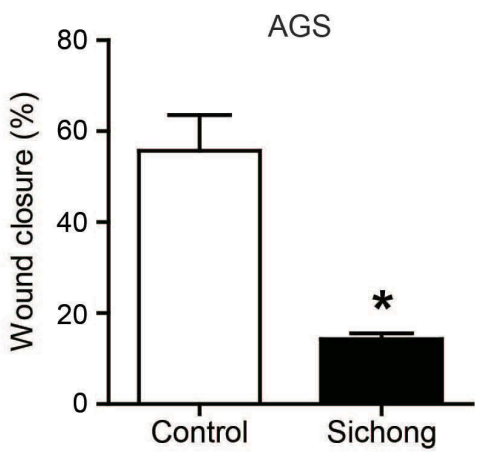

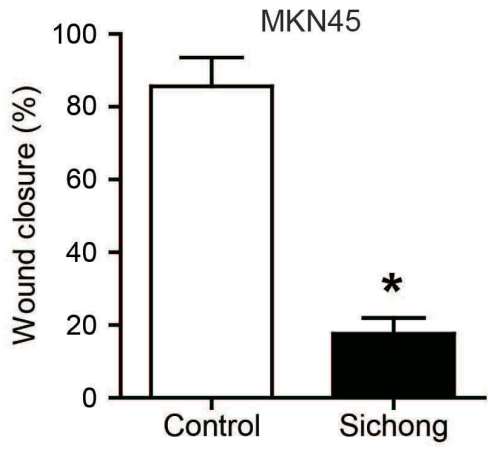

C
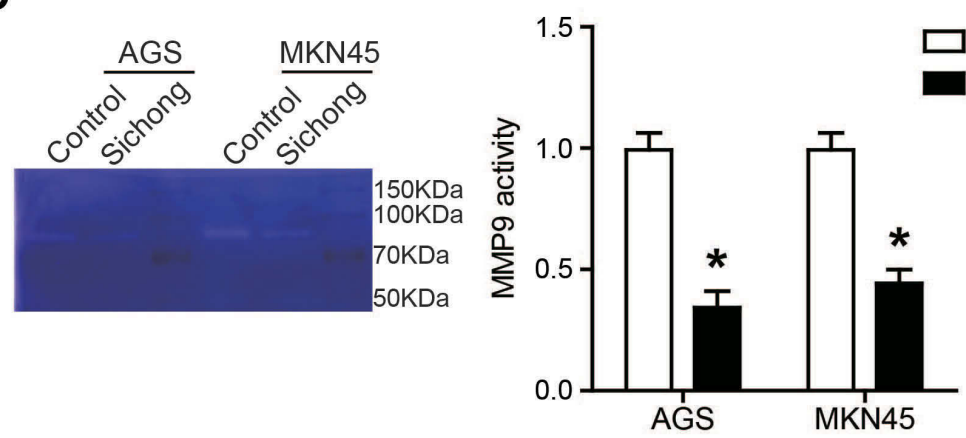

Figure 3 Sichong formula treatment inhibited the wound healing of human gastric cancer cells. (A) and (B) Cell migration was detected in AGS and MKN45 cells using a scratch assay. (C) The activity of MMP9 was detected by gelatin zymography. The treatment regimen of Sichong formula was $80 \mu \mathrm{g} / \mathrm{mL}$ for 48 hrs. All experiments were performed at 3 times. $* P<0.05$.

Abbreviation: MMP9, matrix metalloproteinase 9.

vs $8.720 \pm 0.28 \%, P<0.05)$. However, the induction of Sichong formula in gastric cancer cell apoptosis was significantly stronger than that in normal gastric mucosal epithelial cells. These data suggested that cell apoptosis pathway was activated in Sichong formula-treated gastric cancer cells.

\section{Sichong formula induces autophagy and inhibits AKT signaling pathway in gastric cancer cells}

Cellular autophagy is the process by which cells use lysosomes to degrade their own damaged organelles and macromolecules under the control of autophagy-related genes. ${ }^{10}$
Increasing evidence indicate that cell autophagy also promotes cell death, probably due to degradation of survival proteins or cell energy exhaustion. ${ }^{10,11}$ Here, we investigated the expression of cell autophagy makers, LC3, Beclin-1, and P62, in Sichong formula-treated gastric cancer cells. As shown in Figure 5A, it was suggested that Sichong formula induced increased expression of LC3-II and Beclin-1 and downregulation of P62. Emerging evidence show that AKT pathway is a key signaling pathway in the regulation of a variety of biological processes, which increases cell growth, survival and movements. ${ }^{12}$ Here, we observed that Sichong formula led to decreased phosphorylation level of AKT and expression of downstream effector 
A
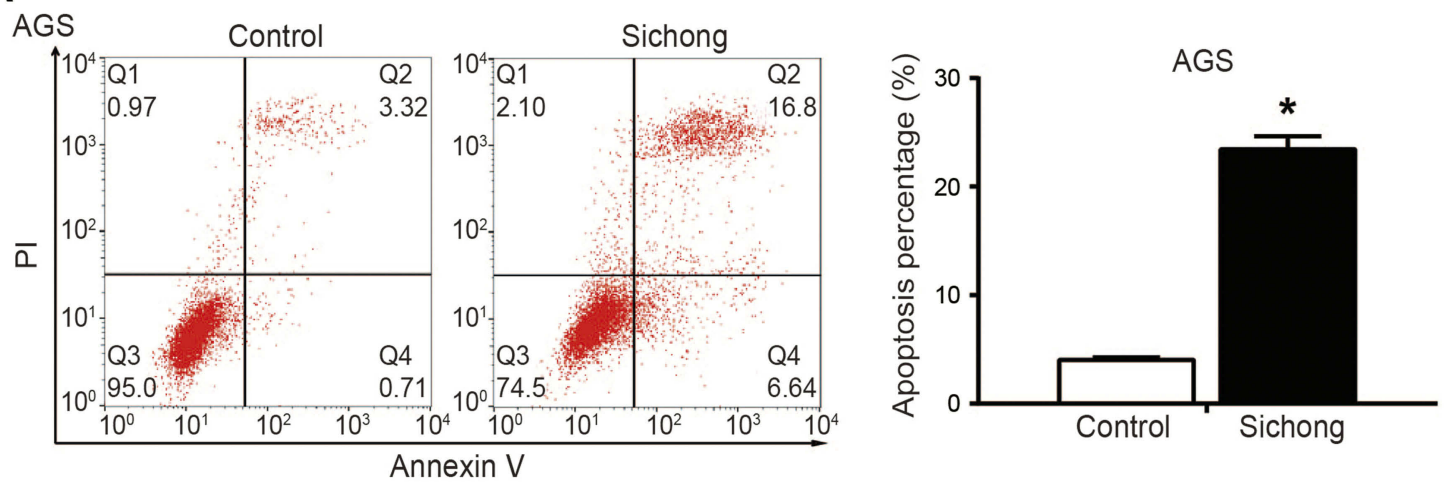

B
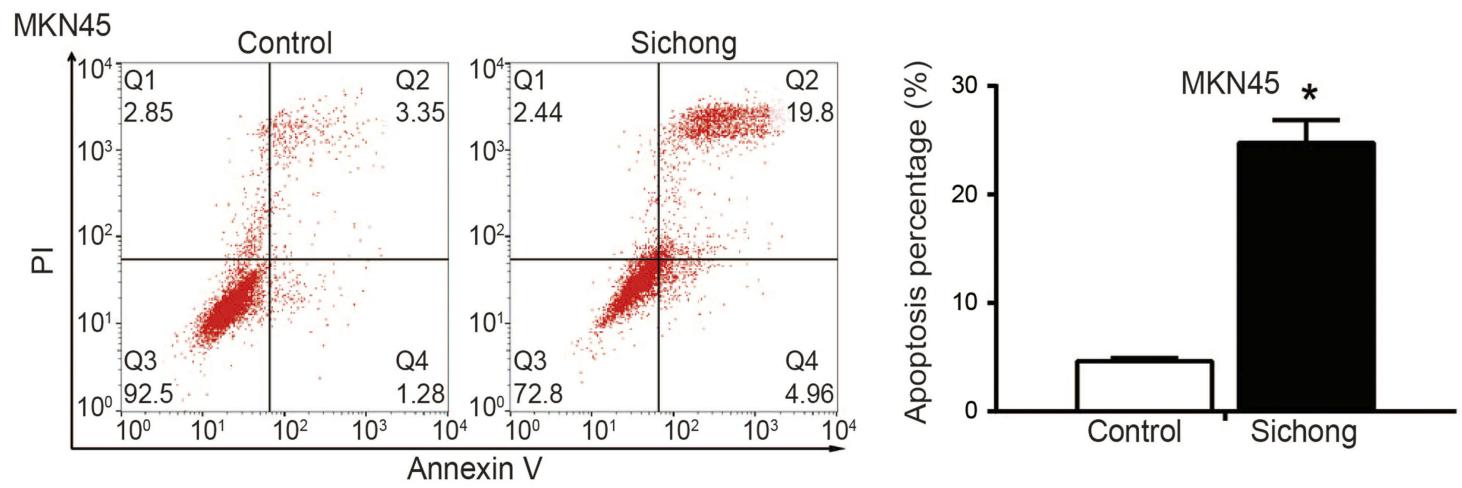

C
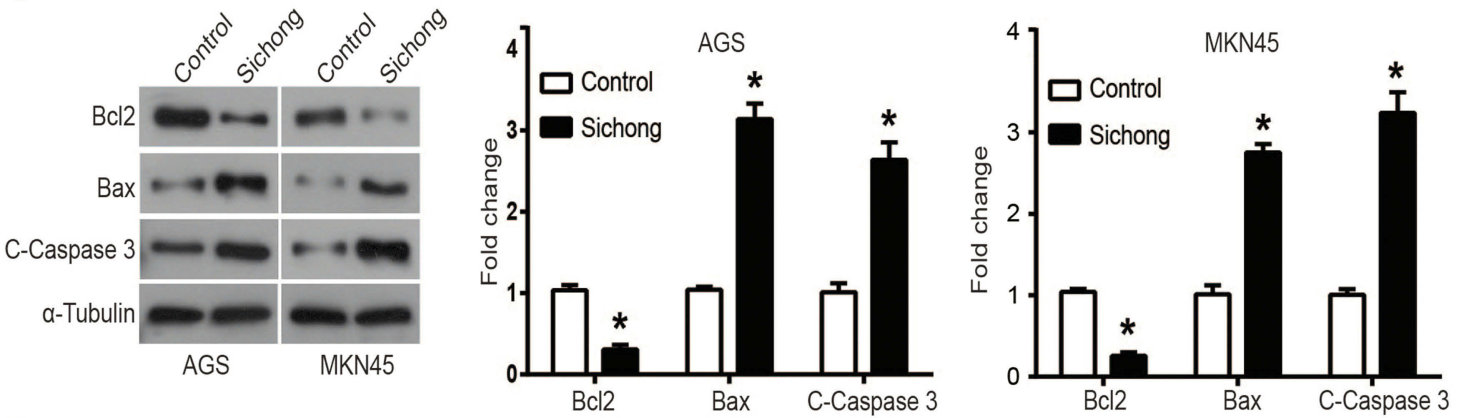

D
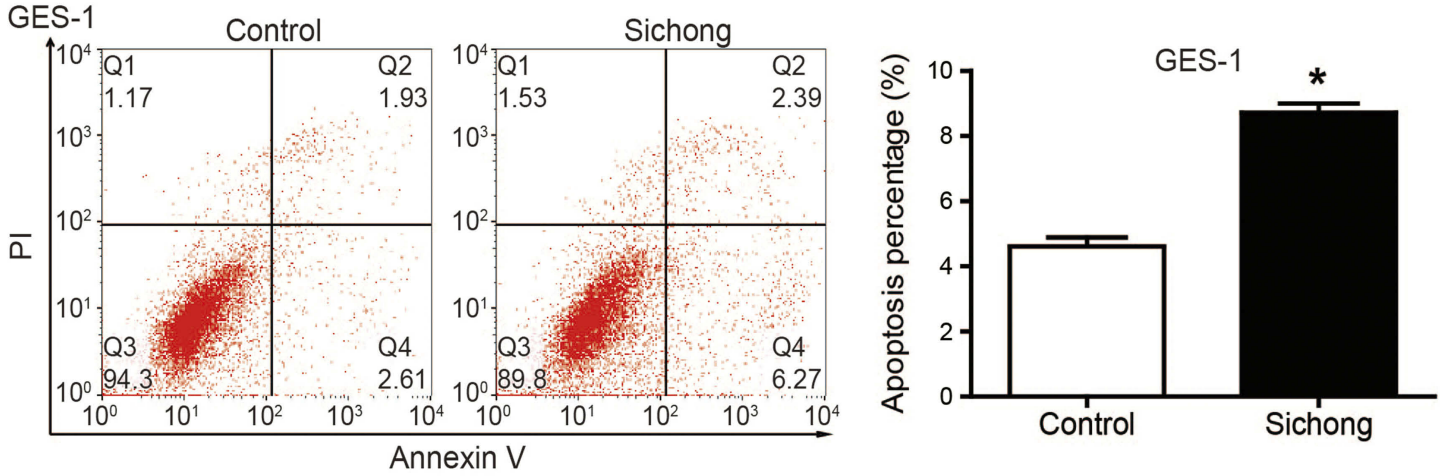

Figure 4 Sichong formula treatment induced apoptosis in gastric cancer cells through regulating Bcl2/Bax and caspase cascade. (A) and (B) cell apoptosis of AGS and MKN45 cells were analyzed by flow cytometry and Flowjo software. (C) Apoptosis-related proteins Bcl2, Bax, and C-Caspase 3 were detected by Western blot. The treatment regimen of Sichong formula was $80 \mu \mathrm{g} / \mathrm{mL}$ for 48 hrs. (D) cell apoptosis of GES-I cells was analyzed by flow cytometry and Flowjo software. All experiments were performed at 3 times. $* P<0.05$. 

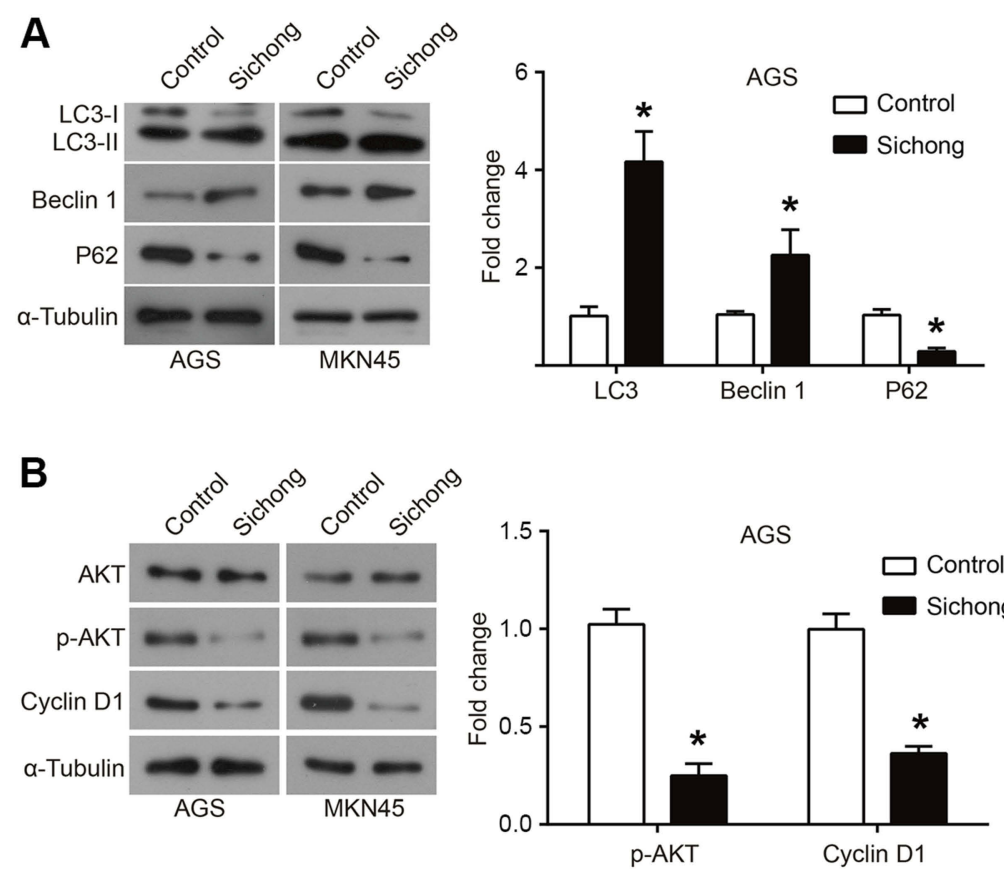
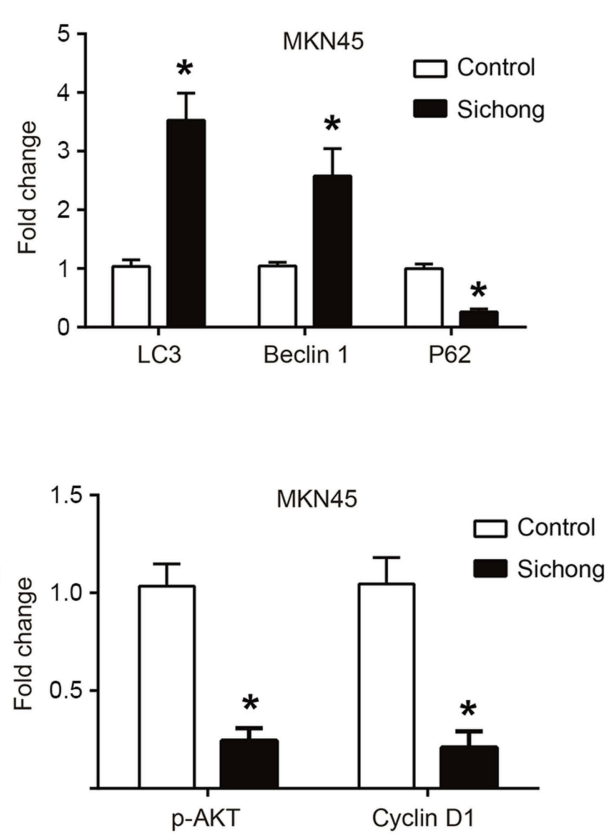

Figure 5 Sichong formula treatment induced cell autophagy and inhibited the activation of AKT signaling pathway. (A) Autophagy-related biomarkers LC3, Beclin-I and P62 were detected in AGS and MKN45 cells using Western blot after treatment of Sichong formula. (B) AKT signaling pathway members AKT, phosphorylated AKT (p-AKT) and Cyclin DI were detected in AGS and MKN45 cells using Western blot after treatment of Sichong formula. The treatment regimen of Sichong formula was $80 \mu \mathrm{g} / \mathrm{mL}$ for $48 \mathrm{hrs}$. All experiments were performed at 3 times. $* P<0.05$.

Cyclin D1, which indicated that AKT pathway was inactivated.

\section{Discussion}

TCM provides a rich source of potential chemopreventive and therapeutic agents for the treatment of cancer. Rigorous and systematic evaluations are, however, necessary to establish the efficacy of TCM formulas and transform traditional practices into science-based medicines. ${ }^{13,14}$ Zhou et al report that Vanillin derivative 6-bromoisovanillin could inhibit HepG2 cell proliferation and induce obviously G2/M phase arrest. $^{15}$ Regarding gastric cancer, $\mathrm{Mu}$ et al report that Baicalein inhibits gastric cancer growth in vitro and mouse subcutaneous xenograft model and induces cell cycle arrest and apoptosis. ${ }^{9}$ Zhu et al report that TCM Ka-Sai-Ping exerts potent antitumor activity in gastric cancer through inducing cell autophagy. ${ }^{16}$ Sichong formula is a combination of several traditional insect medicines, which has been proved to be effective in the treatments of hepatocellular carcinoma. In this study, we demonstrated that Sichong formula suppressed the proliferation and migration and promoted autophagy in gastric cancer cell lines, AGS and MKN45. Furthermore, it was found that the antitumor properties of Sichong formula were, at least partly, mediated by downregulation of AKT signaling pathway.
Uncontrolled cell proliferation and apoptosis are important features of tumors. Therefore, modulation of proliferation and apoptosis of cancer cells is a common and effective tumor treatment strategy. In this study, we found that Sichong formula could inhibit the proliferation of AGS and MKN45 cells in a dose- and time-dependent manner. Moreover, the cologenic ability of human gastric cancer cells was also downregulated by treatment of Sichong formula. Flow cytometry analysis revealed that Sichong formula promoted apoptosis of AGS and MKN45 cells. Although Sichong formula also promoted the apoptosis of normal gastric mucosal cells, its effect was significantly weaker than the apoptosis of gastric cancer cells. In the course of formula treatment of cancer, damage to normal cells is unavoidable. The regulation of apoptosis was in charge of a series proapoptotic and antiapoptotic molecules in the cell. Bcl-2 family plays an important role in the apoptotic pathway. $\mathrm{Bax}$ and $\mathrm{Bcl} 2$ are, respectively, proapoptosis and antiapoptosis members of $\mathrm{Bcl} 2$ family, and the elevation of $\mathrm{Bax} / \mathrm{Bcl} 2$ ratio will cause apoptosis through caspase cascade. ${ }^{17}$ In the present study, Sichong formula treatment increased the expression of proapoptosis protein Bax and decreased antiapoptosis protein Bcl2, thus promoting the activation of Caspase 3, which might be the mechanism underlying apoptosis-inducing property of Sichong formula. 
High metastatic potential is an important cause of poor prognosis and high mortality in patients with gastric cancer. Therefore, exploring drugs that can inhibit tumor migration is an effective strategy for tumor therapy. Here, we demonstrated that Sichong formula could inhibit the migration and invasion abilities of human AGS and MKN45 cells. In the pathological process of tumor invasion and migration, it is necessary for tumor cells to overcome the binding of extracellular matrix. MMP9, as a MMP enzyme, is responsible for the breakdown of extracellular matrix through its proteolytic activity. ${ }^{18}$ Our data suggested that the proteolytic activity of MMP9 was significantly downregulated when gastric cancer cells were treated with Sichong formula.

The basal level of autophagy is necessary to maintain cell homeostasis, while autophagy participates in the pathophysiological processes of aging, differentiation and development, immune regulation, tumors, and other diseases. ${ }^{19}$ Recent studies have revealed that numerous TCM-derived compounds are important regulators of cell autophagy. Here we found that Sichong formula treatment significantly increased the expression of autophagosome marker LC3-II and Becline-1 and decreased the expression of P62, which implicated that cell autophagy was promoted. The AKT signaling pathway acts as a major mediator of cell survival signals and has frequently been found to be activated in primary gastric carcinomas. ${ }^{20,21}$ Targeted inhibition of AKT will cause apoptosis and cell cycle arrest in gastric cancer. $^{20,21}$ When stimulated by survival signals inside and outside the cell, AKT will be converted to a phosphorylated form, which further regulates the expression of downstream effector proteins such as Cyclin D1, thus promoting cell proliferation. ${ }^{22}$ Here, we found that Sichong formula treatment led to a decreased phosphorylation level of AKT and further downregulated the expression of Cyclin D1, which implicated that AKT pathway might be the main mechanism for antitumor activity of Sichong formula. In this study, we found that Sichong formula could exert antitumor effects in gastric cancer cells. However, there is still a long way to go before it is applied to the clinical treatment of gastric cancer, including exploring the general dose, side effects, reagent forms, and active ingredients.

\section{Conclusion}

In conclusion, we report that Sichong formula, a novel TCM, inhibits the proliferation and migration and induces apoptosis and autophagy in human gastric cancer cells. Sichong formula may exert its antitumor function. Our results provide a new potential treatment option for patients with gastric cancer.

\section{Acknowledgments}

This study was supported by Shandong Traditional Chinese Medicine Science and Technology Development Plan (Grant No 2017-061) and Key research and development plan of Shandong Province (Grant No 2017GSF19104). We thank Guangdong Xie and Pengfei Wang for helpful discussions and provision of cell line.

\section{Disclosure}

The authors report no conflicts of interest in this work.

\section{References}

1. Ferlay J, Soerjomataram I, Dikshit R, et al. Cancer incidence and mortality worldwide: sources, methods and major patterns in GLOBOCAN 2012. Int $J$ Cancer. 2015;136(5):E359-E386. doi:10.1002/ijc. 29210

2. Li P, Chen $\mathrm{S}$, Chen $\mathrm{H}$, et al. Using circular RNA as a novel type of biomarker in the screening of gastric cancer. Clin Chim Acta. 2015;444:132-136. doi:10.1016/j.cca.2015.02.018

3. Li T, Mo X, Fu L, Xiao B, Guo J. Molecular mechanisms of long noncoding RNAs on gastric cancer. Oncotarget. 2016;7(8):8601.

4. Sarbia M, Becker KF, Höfler H. Epidemiology of upper gastrointestinal malignancies. Semin Oncol. 2004;31(4):450-464.

5. Xiong F, Jiang M, Huang Z, et al. A novel herbal formula induces cell cycle arrest and apoptosis in association with suppressing the $\mathrm{PI} 3 \mathrm{~K} / \mathrm{AKT}$ pathway in human lung cancer A549 cells. Integr Cancer Ther. 2014;13(2):152-160. doi:10.1177/1534735413503544

6. Wang X, Song ZJ, He X, et al. Antitumor and immunomodulatory activity of genkwanin on colorectal cancer in the APC(Min $/+)$ mice. Int Immunopharmacol. 2015;29(2):701-707. doi:10.1016/j.intimp. 2015.09.006

7. Wu H, Wang W, Tong S, Wu C. Nucleostemin regulates proliferation and migration of gastric cancer and correlates with its malignancy. Int J Clin Exp Med. 2015;8(10):17634.

8. Wang W, Li Y, Chen Y, et al. Ethanolic extract of Traditional Chinese Medicine (TCM) gamboge inhibits colon cancer via the Wnt/beta-catenin signaling pathway in an orthotopic mouse model. Anticancer Res. 2018;38(4):1917-1925. doi:10.21873/anticanres.12429

9. Mu J, Liu T, Jiang L, et al. The traditional chinese medicine baicalein potently inhibits gastric cancer cells. J Cancer. 2016;7(4):453. doi: $10.7150 /$ jca. 13548

10. Denton D, Xu T, Kumar S. Autophagy as a pro-death pathway. Immunol Cell Biol. 2014;93(1):35-42. doi:10.1038/icb.2014.85

11. Teplova I, Lozy F, Price S, et al. ATG proteins mediate efferocytosis and suppress inflammation in mammary involution. Autophagy. 2013;9(4):459-475. doi:10.4161/auto.23164

12. Zou R, Chen X, Jin X, et al. Up-regulated BCAR4 contributes to proliferation and migration of cervical cancer cells. Surg Oncol (Oxford). 2018;27(2):306-313. doi:10.1016/j.suronc.2018.05.013

13. Zhang $\mathrm{P}$, Wang $\mathrm{X}$, Xiong $\mathrm{S}$, et al. Genome wide expression analysis of the effect of the chinese patent medicine zilongjin tablet on four human lung carcinoma cell lines. Phytother Res. 2011;25 (10):1472-1479. doi:10.1002/ptr.3445 
14. Wang P, She G, Yang Y, et al. Synthesis and biological evaluation of new ligustrazine derivatives as anti-tumor agents. Molecules. 2012;17 (5):4972-4985. doi:10.3390/molecules17054972

15. Bo Zhang LL, Guan H, Wang H, Zhang Z, Zhou P. HepG2 cell cycle related gene transcriptional profiles are altered by a novel vanillin derivative BVAN08. J Med Discov. 2017;2(3):jmd17036.

16. Zhu M-L, Lu J-X, Pan G-P, et al. Traditional Chinese medicine Ka-SaiPing suppresses the growths of gastric cancers via induction of autophagy. Oncotarget. 2017;8(56):95075-95082. doi:10.18632/oncotarget.18041

17. Radha G, Raghavan SC. BCL2: A promising cancer therapeutic target. Biochim Biophys Acta. 2017;1868(1):309-314. doi:10.1016/j. bbcan.2017.06.004

18. Zhang X, Min J, Wang Y, et al. RABEX-5 plays an oncogenic role in breast cancer by activating MMP-9 pathway. J Exp Clin Cancer Res. 2013;32(1):52. doi:10.1186/1756-9966-32-52
19. Cui B, Yu J-M. Autophagy: a new pathway for traditional Chinese medicine. J Asian Nat Prod Res. 2018;20(1):14-26. doi:10.1080/ 10286020.2017.1374948

20. Sangawa A, Shintani M, Yamao N, Kamoshida S. Phosphorylation status of Akt and caspase-9 in gastric and colorectal carcinomas. Int J Clin Exp Pathol. 2014;7(6):3312-3317.

21. Riquelme I, Tapia O, Espinoza JA, et al. The gene expression status of the PI3K/AKT/mTOR pathway in gastric cancer tissues and cell lines. Pathol Oncol Res. 2016;22(4):797-805. doi:10.1007/s12253016-0066-5

22. Li D, Qu X, Hou K, et al. PI3K/Akt is involved in bufalin-induced apoptosis in gastric cancer cells. Anticancer Drugs. 2009;20 (1):59-64. doi:10.1097/CAD.0b013e3283160fd6
OncoTargets and Therapy

\section{Publish your work in this journal}

OncoTargets and Therapy is an international, peer-reviewed, open access journal focusing on the pathological basis of all cancers, potential targets for therapy and treatment protocols employed to improve the management of cancer patients. The journal also focuses on the impact of management programs and new therapeutic

\section{Dovepress}

agents and protocols on patient perspectives such as quality of life adherence and satisfaction. The manuscript management system is completely online and includes a very quick and fair peer-review system, which is all easy to use. Visit http://www.dovepress.com/ testimonials.php to read real quotes from published authors. 